The Common Agricultural Policy of the European Union the present and the future

EU Member States

point of view 



\section{INSTITUTE OF AGRICULTURAL AND FOOD ECONOMICS NATIONAL RESEARCH INSTITUTE}

\section{The Common Agricultural Policy of the European Union - the present and the future}

\section{EU Member States point of view}

Editors:

dr Marek Wigier

prof. dr hab. Andrzej Kowalski

Proceedings of the International Scientific Conference

"The Common Agricultural Policy of the European Union - the present and the future" Multi-Annual Programme 2015-2019

"The Polish and the EU agricultures 2020+. Challenges, chances, threats, proposals" 5-7 December 2017 Stare Jabłonki, Poland

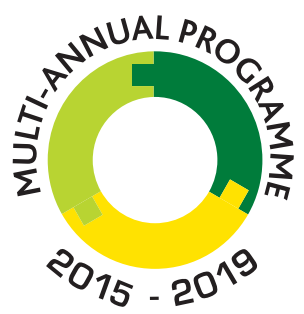

THE POLISH AND THE EU AGRICULTURES 2020+ CHALLENGES, CHANCES, THREATS, PROPOSALS

Warsaw 2018 
This monograph was prepared under the Multi-Annual Programme 2015-2019

"The Polish and the EU agricultures 2020+. Challenges, chances, threats, proposals".

The publication is a collection of selected papers delivered at the 22th edition of the International Scientific Conference organized by the Institute of Agricultural and Food Economics - National Research Institute. The theme of the conference was "The Common Agricultural Policy of the European Union the present and the future. The conference was placed on 5-7 December 2017 in Stary Jabłonki in Poland. Common Agricultural Policy was and still is one of the key pillars of European integration. Published in two volumes materials refer directly to the current and future of the CAP in EU and non EU member states, the strategic objectives and principles of agricultural policy for the agri-food sector and rural areas, address the issues of equilibrium between agriculture, forestry and land use, relate to the dilemmas for the EU budget and the CAP after 2020, CAP instruments and their adjustment, transformations of the rural economy and programming of the rural and agricultural policy, as well as productivity and production efficiency and tensions between sectoral action and between different models of territorial activities.

In the Scientific Committee of the Conference was participated: Prof. Andrzej Kowalski (IAFE-NRI, Poland), Prof. Drago Cvijanonivić (University of Kragujevac, Serbia), Prof. Thomas Doucha (IAEI, Czech Republic), Noureddin Driouech, PhD (CIHEAM, Italy), Prof. Szczepan Figiel (IAFE-NRI, Poland), Prof. Masahiko Gemma (Waseda University, Japan), Prof. Wojciech Józwiak (IAFE-NRI, Poland), Prof. Jacek Kulawik (IAFE-NRI, Poland), Prof. Yuriy Oleksiyovych Lupenko (IAE, Ukraina), Prof. Věra Majerová (CULS, Prague), Prof. Dimitre Nikolov (IAE, Bulgaria), Maire Nurmet, PhD (EMÜ, Estonia), Prof. Gabriel Popescu (ASE, Romania), Norbert Potori, PhD (AKI, Hungary), Prof. Włodzimierz Rembisz (IAFE-NRI, Poland), Piotr Szajner, PhD (IAFE-NRI, Poland), Prof. Alina Sikorska (IAFE-NRI, Poland), Prof. Jonel Subić (IAE, Serbia), Prof. Samuele Trestini (UNIPD, Italy), Prof. Olga Varchenko (Bila Tserkva National Agrarian University, Ukraine), Dipl.-Ing. Klaus Wagner (AWI, Austria), Marek Wigier, PhD (IAFE-NRI, Poland), Prof. Józef St. Zegar (IAFE-NRI, Poland)

In the Organising Committee of the Conference was participated: Małgorzata Bułkowska (IAFE-NRI, Poland), Anna Hankiewicz (IAFE-NRI, Poland), Joanna Jaroszewska (IAFE-NRI, Poland), Joanna Korczak (IAFE-NRI, Poland), Krzysztof Kossakowski (IAFE-NRI, Poland), Irena Mikiewicz (IAFE-NRI, Poland), Małgorzata Mikołajczyk (IAFE-NRI, Poland), Lech Parzuchowski (IAFE-NRI, Poland), Ewa Sierakowska (IAFE-NRI, Poland), Paulina Smakosz (IAFE-NRI, Poland), Leszek Ślipski (IAFE-NRI, Poland), Marek Wigier, PhD (IAFE-NRI, Poland).

Reviewers:

Professor Dimitre Nikolov, Institute of Agricultural Economics, Sofia, Bulgaria

Professor Gabriel Popescu, The Bucharest University of Economic Studies, Bucharest, Romania

Professor Samuele Trestini, University of Padva, Italy

Proofreader

Katarzyna Mikulska

Technical editors:

Joanna Jaroszewska, Barbara Pawtowska, Ewa Sierakowska, Kamila Tomaszewska,

Barbara Walkiewicz

Translated by

Summa Linguae S.A.

Cover Project

Leszek Ślipski

ISBN 978-83-7658-743-1

DOI: $10.30858 / \mathrm{pw} / 9788376587431$

Instytut Ekonomiki Rolnictwa i Gospodarki Żywnościowej

- Państwowy Instytut Badawczy

ul. Świętokrzyska 20, 00-002 Warszawa

tel.: (22) 5054444

faks: (22) 5054636

e-mail:dw@ierigz.waw.pl

http://www.ierigz.waw.pl 


\section{Contents}

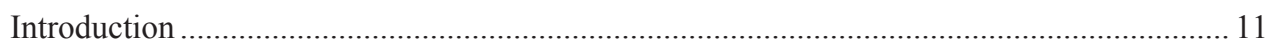

Dr Marek Wigier

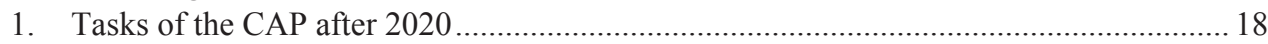

Dr hab. Julian Krzyżanowski

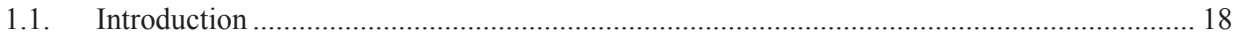

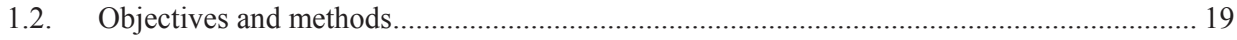

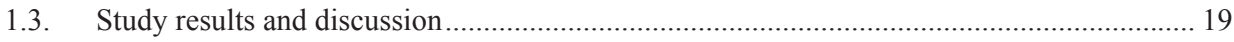

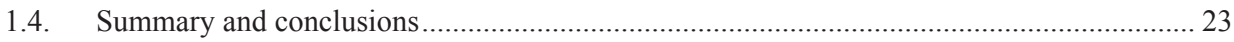

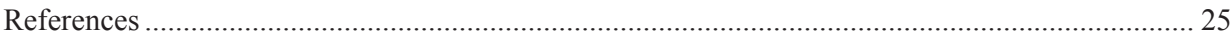

2. An assessment of the regional impacts of post-2020 CAP budgetary cuts on production

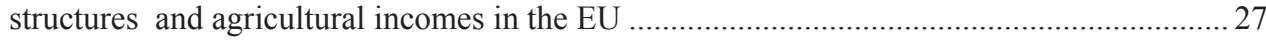

PhD Norbert Potori, PhD János Sávoly, PhD Szabolcs Biró

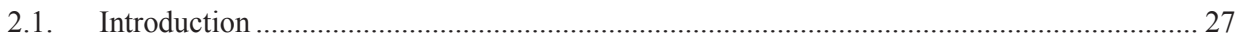

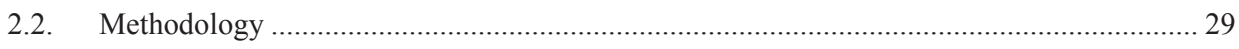

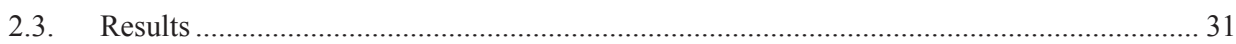

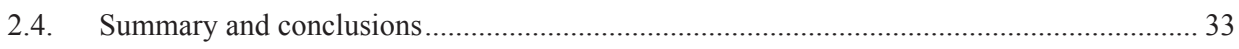

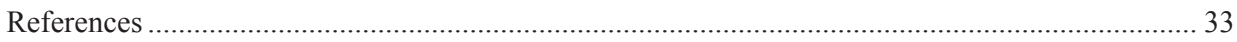

3. Is there room for financial instruments in the Common Agricultural Policy? Casus of

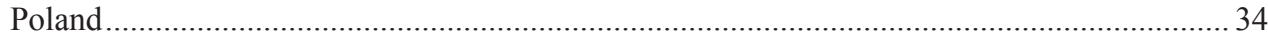

Prof. dr hab. Jacek Kulawik, PhD Barbara Wieliczko, PhD Michat Soliwoda

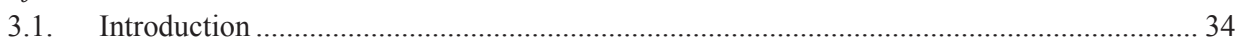

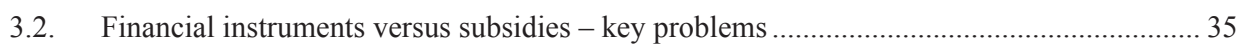

3.3. The use of financial instruments under the EU policy ......................................................... 37

3.4. Example of the use of FI in the 2014-2020 programming period ......................................... 38

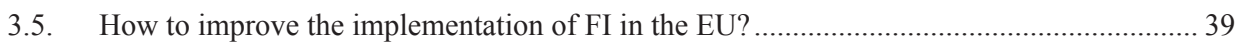

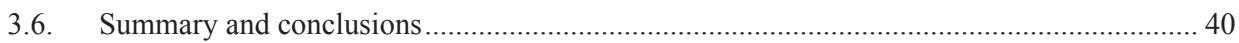

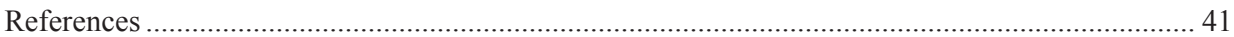

4. The past, present and future of the CAP - the Hungarian viewpoint ............................. 43

Dr Tamás Mizik

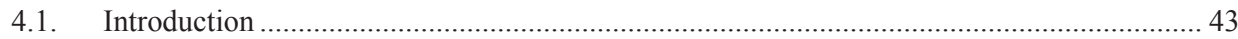

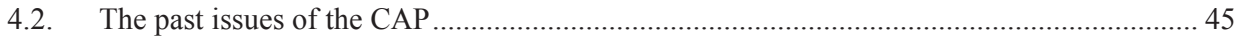

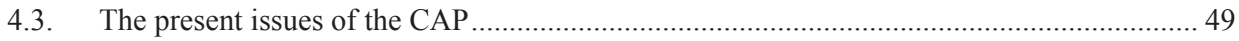

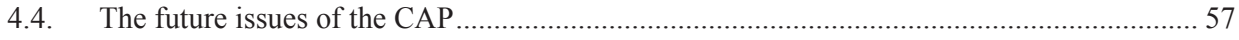

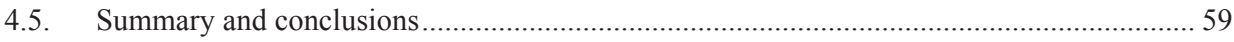

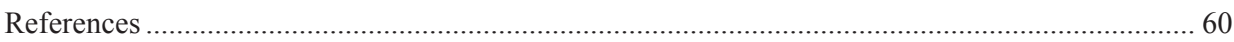


5. Going beyond the Rural Development Programme: a Master Plan for Austria's rural areas in the framework of the CAP

Dip.-Ing. Klaus Wagner

5.1. Introduction

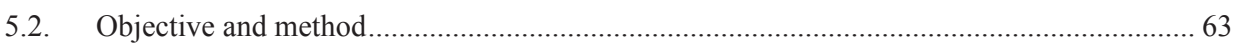

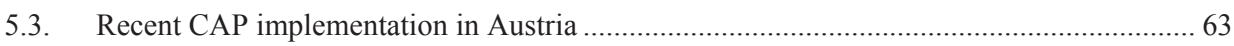

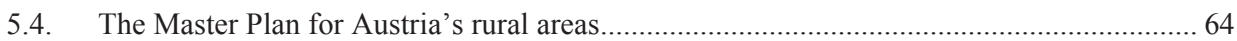

5.5. CAP in the system of the EU policy objectives and in the view of regional science

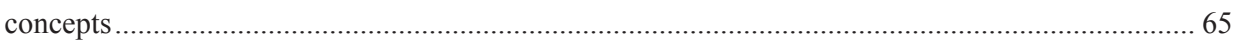

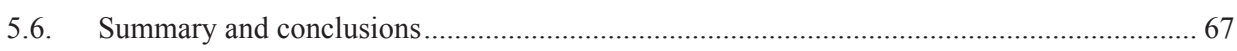

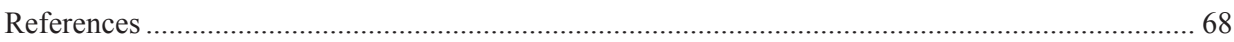

6. Possibilities to connect the Romanian agricultural research to the market requirements 69 Prof. Gabriel Popescu

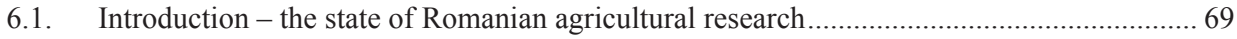

6.2. The problems faced by agricultural research since 1990 ..................................................... 71

6.3. Possible solutions for the recovery of Romanian agricultural research ................................ 76

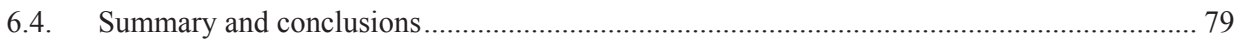

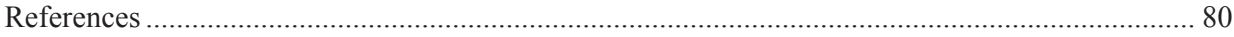

7. Price relationships of the production factors as exogenous determinants of production in agriculture.

Prof. dr hab. Włodzimierz Rembisz, PhD Adam Waszkowski

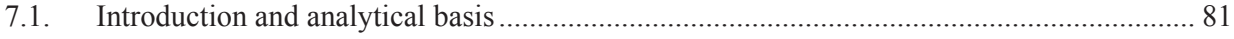

7.2. Relationships of prices of the capital, labour and land factors - hypothetical approach...... 83

7.3. Relationships of prices of the capital, labour and land factors - empirical approach .......... 84

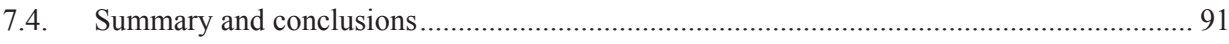

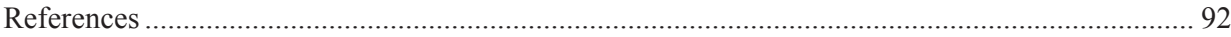

8. Effects of direct payments on agricultural development in Bulgaria ............................. 93 PhD Bozhidar Ivanov

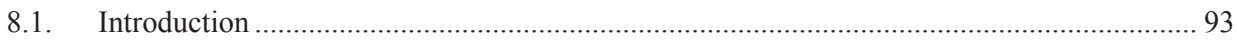

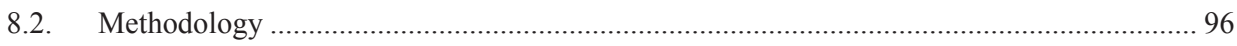

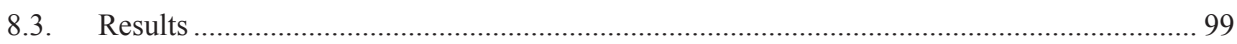

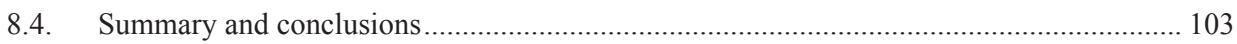

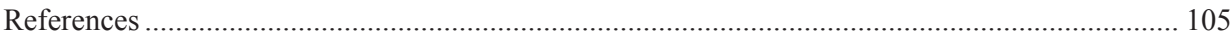

9. Re-adjusting risk management within the CAP: evidences on the implementation of the

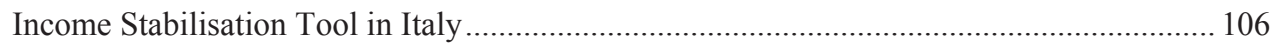
Prof. Samuele Trestini, PhD Elisa Giampietri

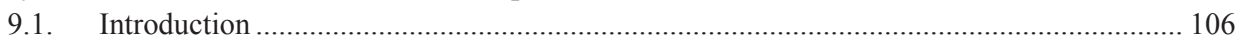

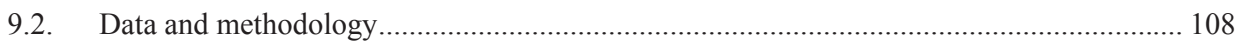




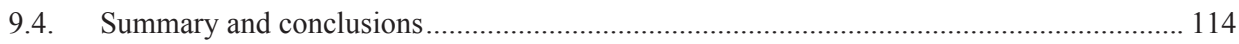

References

10. Comparison of risk management tools under the CAP of the EU, the US Farm Bill

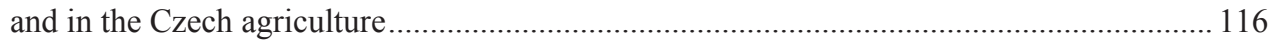
Ing. Václav Vilhelm, CSc., Ing. Sumudu Namali Gouri Boyinová, PhD Jindřich Špička

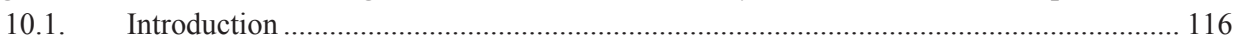

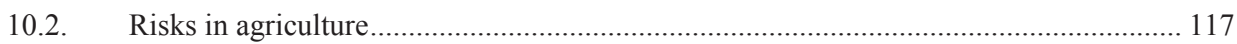

10.3. Risk management policy in the United States Farm Bill 2014 _..................................... 118

10.4. Risk management policy of the European Union's CAP ................................................ 119

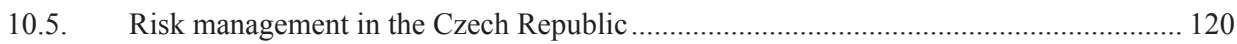

10.6. Comparative analysis of risk management policies ........................................................ 121

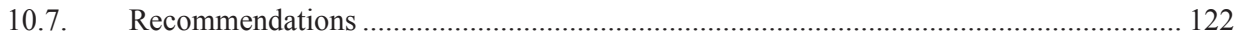

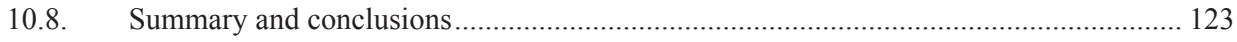

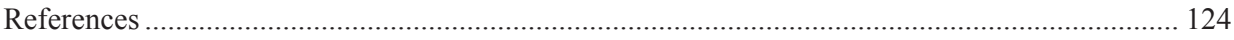

11. Factors determining the crop insurance level in Poland taking into account the level

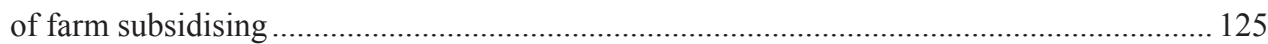

Prof. Adam Was, PhD Pawet Kobus

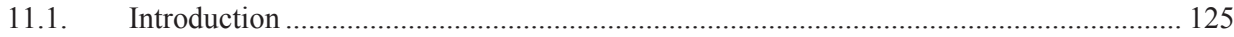

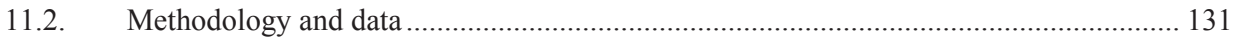

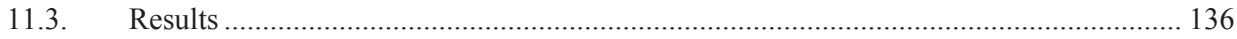

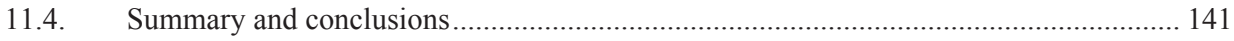

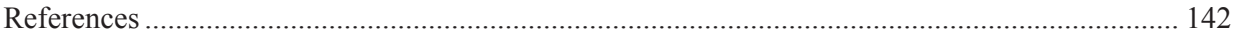

12. Farms and agricultural enterprises for development of sustainable and smart cooperatives: a multifactor approach using digital farm management ............................... 147 Prof. dr habil Adriana Mihnea, Prof. dr Dimitre Nikolov, dr Krasimir Kostenarov

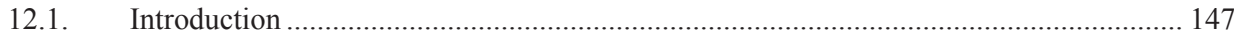

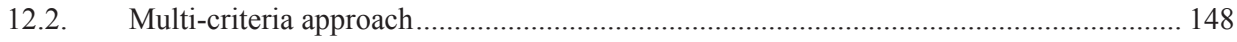

12.3. Construction of Farm Management Model ................................................................ 150

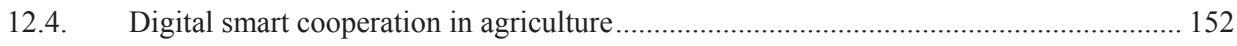

12.5. Application of the ANP Farm Management Model ....................................................... 154

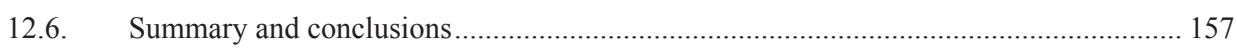

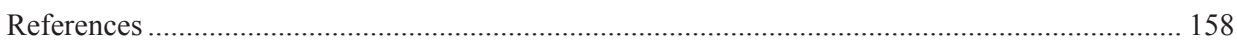

13. Brexit - potential implications for the Polish food sector .............................................. 159

Dr Katarzyna Kosior, Dr Łukasz Ambroziak

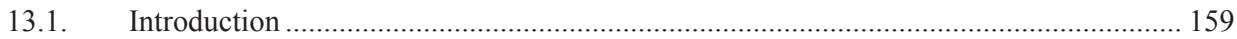

13.2. Negotiations on Brexit - what should be the model of the future relations? ..................... 161

13.3. The future of the EU finances and the CAP in the context of Brexit .............................. 163 
13.4. Impact of possible changes in the CAP budget on the net balance of Poland and transfers to the Polish agriculture.

13.5. The potential impact of Brexit on agri-food trade between Poland and the United

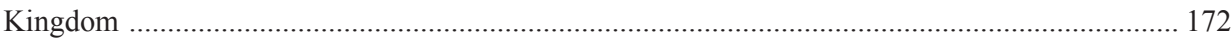

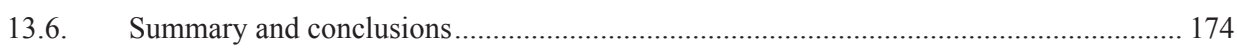

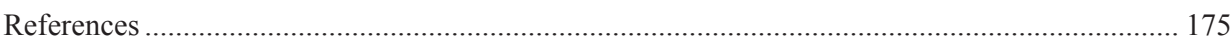

14. The Transatlantic Trade and Investment Partnership (TTIP): a threat or an opportunity for the EU-Mediterranean agriculture and agri-food sector? An exploratory survey ........... 177 Dipl.-Ing. Katja Pietrzyck, PhD Noureddin Driouech, Prof. Brigitte Petersen

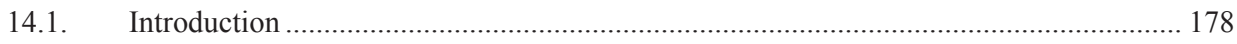

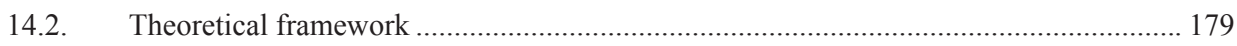

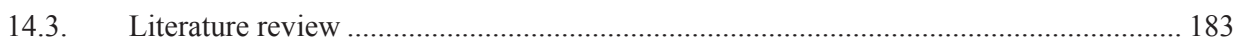

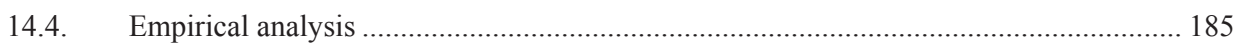

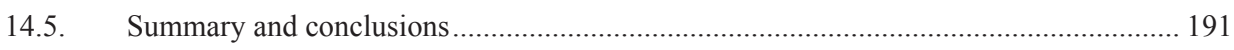

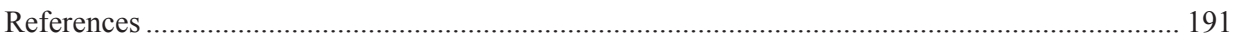

Appendix I: Overview of trade statistics regarding selected products ........................................... 195

15. The concept of short supply chains in the food economy............................................. 196

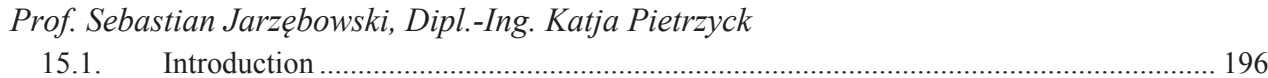

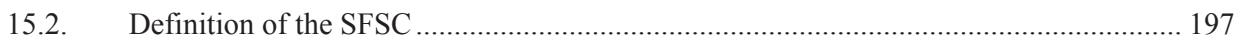

15.3. Development of short supply chains in Europe............................................................. 201

15.4. Global context of European short supply chains ........................................................... 205

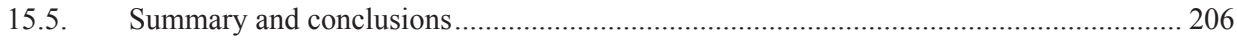

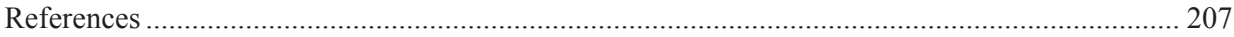

16. The CAP implementation in Wallonia - today performance and questions for the future -

A brief supplementary comment from Warmia and Mazury perspective............................. 209

PhD Philippe Burny, PhD Benon Gazinski

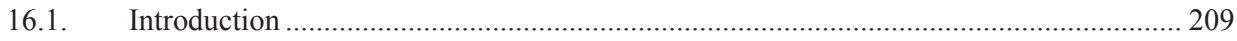

16.2. Implementation of the green payment in Wallonia in 2015 ........................................ 210

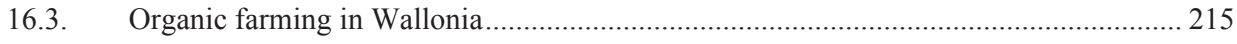

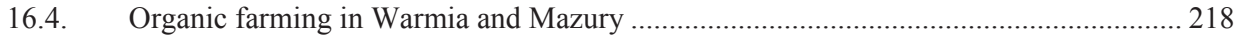

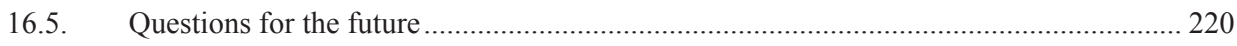

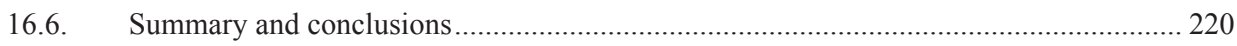

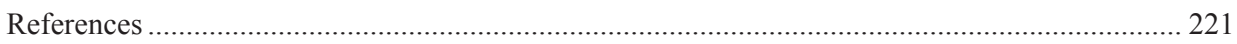

17. Afforestation of agricultural land financed from the RDP 2014-2020 ....................... 224

PhD Marek Zieliński

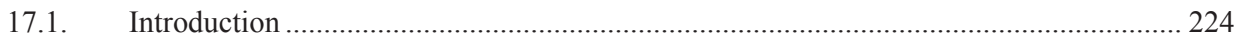

17.2. Natural farming conditions in Poland in regional terms................................................. 225 
17.3. The impact of natural farming conditions in Poland on the economic situation and the possibility of afforestation on farms

17.4. Land afforestation financed from the RDP 2014-2020 in regional terms

17.5. Importance of land afforestations financed under the RDP 2014-2020 in the EU climate policy for 2021-2030.

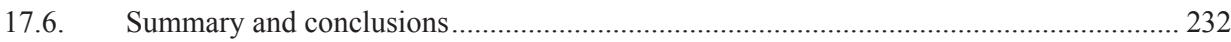

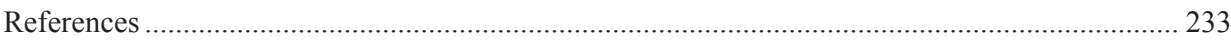

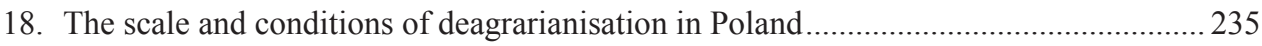

PhD Michat Dudek, PhD Bożena Karwat-Woźniak

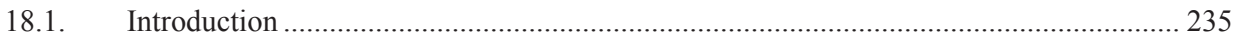

18.2. The conditions of the decrease in employment in agriculture ......................................... 236

18.3. The change in the scale of employment in agriculture in Poland and its conditions....... 238

18.4. The instruments of the Cohesion Policy and agriculture and rural development of the EU

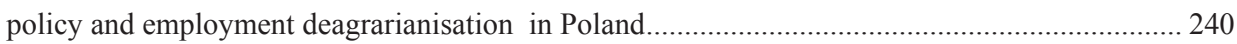

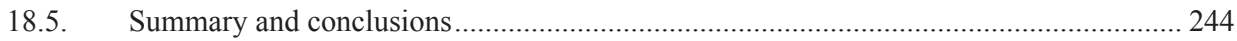

References 245

19. Socio-economic and environmental parameters and results of rural development under the CAP: the case of Bulgaria ................................................................................................ 247 Prof.dr.hab. Julia Doitchinova, Prof.dr.hab. Ivan Kanchev, Ass.Prof. Ralitsa Terziyska PhD, Ass.Prof. Kristina Todorova PhD

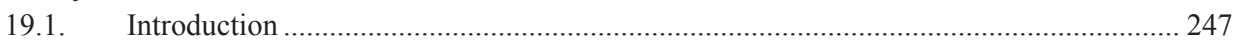

19.2. Changes in Bulgarian rural areas - socio-economic and environmental aspects................ 248

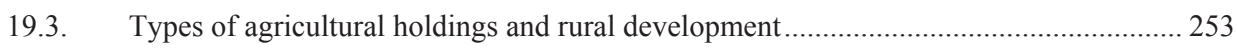

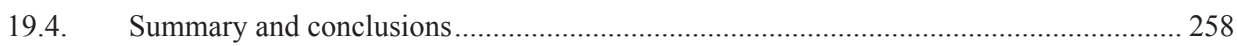

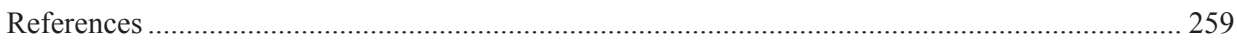

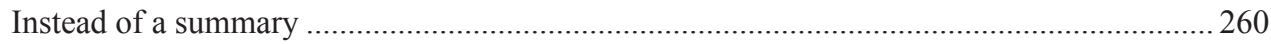

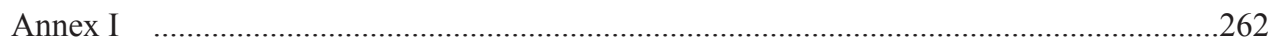




\title{
17. Afforestation of agricultural land financed from the RDP 2014-2020
}

\author{
PhD Marek Zieliński \\ Institute of Agricultural and Food Economics \\ - National Research Institute, Warsaw, Poland \\ zielinski@ierigz.waw.pl
}

DOI: $10.30858 / \mathrm{pw} / 9788376587431.17$

\begin{abstract}
The paper highlights the role of afforestations as an important method for management of agricultural land with adverse natural farming conditions in Poland. In the first place, it assessed natural farming conditions in Poland in regional terms and their impact on the economic situation and the possibility of afforestation on farms. The next step was to assess the state of implementing existing afforestations financed from the RDP 2014-2020. Then, it estimated their contribution to carbon dioxide $\left(\mathrm{CO}_{2}\right)$ sequestration from the atmosphere in the Land Use, Land Use Change and Forestry (LULUCF) area. The paper used the data from the Agency for Restructuring and Modernisation of Agriculture (Agencja Restrukturyzacji i Modernizacji Rolnictwa, ARiMR), Institute of Soil Science and Plant Cultivation - State Research Institute (Instytut Uprawy Nawożenia $i$ Gleboznawstwa - Państwowy Instytut Naukowy, IUNG) and the data from farms conducting accounting for the Polish Farm Accountancy Data Network (Polish FADN) in 2013-2015, as well as the literature data.
\end{abstract}

Keywords: afforestations, RDP 2014-2020, APAV index, LULUCF, $\mathrm{CO}_{2}$

JEL codes: Q15, Q54, Q57

\subsection{Introduction}

In Poland, an important difficulty for farms wishing to conduct the effective agricultural production are often adverse natural farming conditions, as evidenced by the average agricultural production area valorisation (APAV) index amounting to 66.8 points (pts) per 120 achievable points [Jadczyszyn et al., 2013]. What is more, $32.9 \%$ of cadastral districts are characterised by the average APAV index lower than $52 \mathrm{pts}^{24}$. This indicates that these areas have particularly difficult natural conditions to conduct agricultural production, resulting from, inter alia, low soil quality, unfavourable land relief and adverse climate. These lands, due to their low suitability for agriculture, may, therefore, be a potential area for afforestation in the first place.

\footnotetext{
${ }^{24}$ Data from the Institute of Soil Science and Plant Cultivation National Research Institute (IUNG) in Puławy.
} 
In Poland, in 2004-2015 the forest cover increased from 28.7 to $29.5 \%$, i.e. by about 0.8 percentage points (p.p.) [GUS, 2010, 2016a], of which 0.3 p.p. accounted for afforestations made as part of the RDP 2004-2006, 2007-2013, and 2014-2020. As part of the existing RDP, afforestations covered the area of 78.1 thousand ha of land, of which $91.1 \%$ are afforestations financed under the RDP 2014-202025 and 26. This means that a large impact on the increased forest cover in Poland is exerted by afforestations supported under the EU' Common Agricultural Policy. This is particularly important both in the context of meeting the objectives of the National Programme for the Augmentation of Forest Cover (NPAFC), which assumes that by 2020 Poland should achieve the forest cover at the level of $30 \%$ and potential participation of the LULUCF $^{27}$ area in reducing the effort to limit the greenhouse gas emissions from the Effort Sharing Regulation (ESR) area after $2020^{28}$ and 29 .

This paper first assessed natural farming conditions in Poland in regional terms and their impact on the economic situation and the possibility of afforestation in farms. Then, it analysed the state of implementing the existing afforestations financed under the RDP 2014-2020. In addition, in view of the increasing importance of the LULUCF area, including afforestations within the objectives of the EU climate policy for 2021-2030, the paper estimated the contribution of existing afforestations financed from the RDP 2014-2020 to $\mathrm{CO}_{2}$ sequestration from the atmosphere in the LULUCF area.

\subsection{Natural farming conditions in Poland in regional terms}

Among the factors having a significant impact on the economic situation of farms we should identify their natural farming conditions. In the paper, these conditions were described using the APAV index, whose value was determined by the IUNG for each commune and cadastral district in Poland. The structure of this index takes into account such components as: soil quality, agroclimate, hy-

\footnotetext{
${ }^{25}$ Status as of 31.12 .2016$.

${ }^{26}$ Afforestations financed under the RDP 2014-2020 apply to afforestations financed under new commitments, commitments from the RDP 2007-2013 (afforestation premium and/or maintenance premium) and commitments from the RDP 2004-2006 (afforestation premium).

${ }^{27}$ According to the methodology of the Intergovermental Panel on Climate Change (IPCC) in the LULUCF area we estimate the balance of $\mathrm{CO}_{2}$ sequestration from the atmosphere in total from the sectors of forestry land, afforested, deforested, permanent grassland as well as arable, boggy and inhabited land.

${ }^{28}$ The ESR area covers greenhouse gas emissions from the following sectors: transport, waste, construction, fuel processing and transport, industrial processes not included in the ETS area and agriculture [Sytuacja emisyjna..., 2016].

${ }^{29}$ Proposal for a Regulation of the European Parliament and of the Council of 16 October 2017 on the inclusion of greenhouse gas emissions and removals from land use, land use change and forestry into the 2030 climate and energy framework and amending Regulation No 525/2013 of the European Parliament and the Council on a mechanism for monitoring and reporting greenhouse gas emissions and other information relevant to climate change - general approach [Proposal for a Regulation, 2017].
} 
drographic conditions and land relief, and the importance of each of them is proportionate to its impact on the yield of crops [Krasowicz et al., 2011; Jadczyszyn et al., 2013] ${ }^{30}$.

As stressed in the introduction, in Poland the average APAV index is 66.8 points, although it is territorially diversified. In the voivodeships, it ranges from 54.5 points (Podlaskie Voivodeship) to 76.8 points (Opolskie Voivodeship) (Map 1). The largest share of potential UAA with the APAV index lower than 52 points $^{31}$ in the area of potential UAA $^{32}$ in total occurs in the Podlaskie Voivodeship (43.1\%), Pomorskie Voivodeship (27.7\%) and Małopolskie Voivodeship $(25.5 \%)$, while the smallest in the Zachodniopomorskie Voivodeship (1.5\%), Lubelskie Voivodeship (4.1\%) and Kujawsko-Pomorskie Voivodeship $(5.6 \%)$. There are no weak areas for the agricultural production in the Opolskie Voivodeship $^{33}$ (Map 2).

Map 1. APAVindex (points) in the Map 2. Share in \% of potential UAA voivodeships in Poland

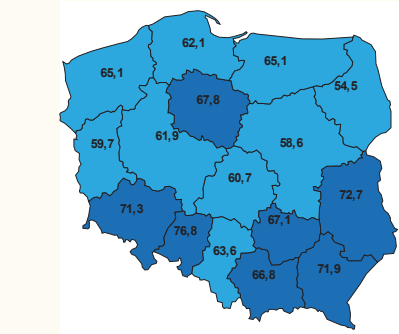

with APAV index below $66.8 \mathrm{pts}$.
with APAV index of at least $66.8 \mathrm{pts}$. with the APAV index below 52 points in the area of potential UAA in total in the voivodeships in Poland

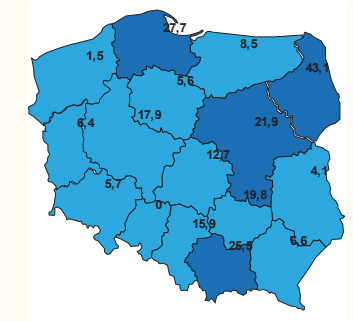

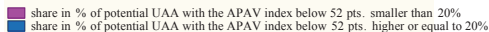

Source: own study based on the IUNG.

In the case of the communes, the average APAV index is contained between $0^{34}$ and 108.3 (commune of Żórawina) ${ }^{35}$. In $58.6 \%$ of the communes, it is lower than the national average ( 66.8 points), of which in $18.2 \%$ of the communes it is lower than 52 points (Map 3). In the remaining $41.4 \%$ of the communes, their vast majority (80.9\%) have the APAV index from 66.8 to 86.8 points.

\footnotetext{
${ }^{30}$ Soil quality is assigned 95 points at a maximum, agroclimate - 15 points and land relief and hydrographic conditions -5 points each. The APAV index calculated as a total of these factors may have the maximum value of 120 pts.

${ }^{31}$ Applies to the potential area of UAA with the APAV index below 52 points according to the register and geodetic area of the country.

${ }^{32}$ Applies to the potential area of UAA in total according to the register and geodetic area of the country.

${ }^{33}$ Data from the IUNG database.

${ }^{34}$ This situation applies to seven urban communes in Poland [IUNG].

${ }^{35}$ Data of the IUNG in Puławy.
} 
Map 3. APAV index (points) in the communes in Poland
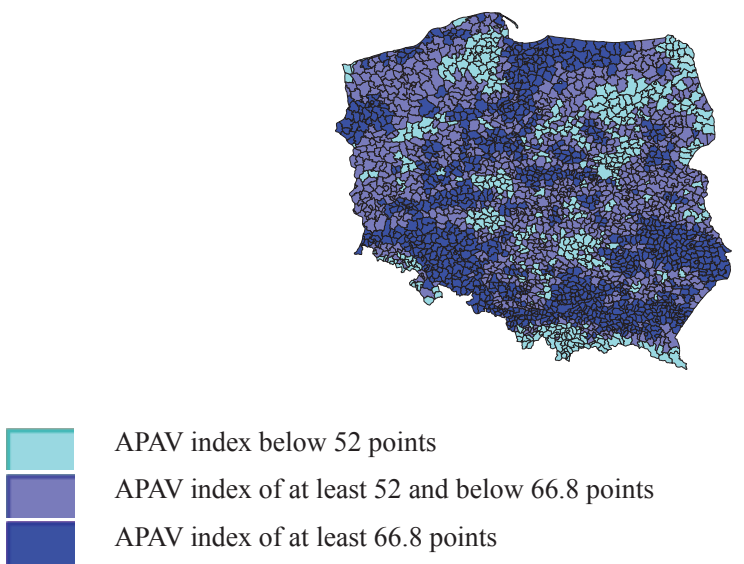

APAV index below 52 points

APAV index of at least 52 and below 66.8 points

APAV index of at least 66.8 points

Source: as in Map 1 and 2.

\subsection{The impact of natural farming conditions in Poland on the economic situation and the possibility of afforestation on farms}

As determined in the previous subchapter, Poland is characterised by the spatial variability of natural farming conditions, with the large share of areas of low suitability for agriculture. One of the important possibilities to manage this type of land is afforestation. The more so that farms can now receive the aid to afforest their own land under the measure Afforestation and creation of afforested areas as part of the RDP 2014-2020. This aid takes a form of support due to the costs incurred for establishing and maintenance of forest stands (support for afforestation and maintenance premium) and lost income from agricultural activities (afforestation premium), but not only. Since 2015, it has been possible to receive additional direct payments to afforested land for the entire duration of the commitment [Przewodnik..., 2016]. According to the figures from Table 1, potential land for afforestation should be sought after on farms from the communes with the APAV index lower than 66.8 points, including primarily on farms specialising in field crops and with mixed production, where average income per 1 ha of UAA in 2013-2015 was lower than the afforestation premium rate (PLN 1215) plus the single area payment rate (PLN 453.7) ${ }^{36}$. This situation is understandable, since one of the important constraints for conducting the profitable agricultural production in the areas with lightweight soils with the low water holding capacity is the absence or scarcity of applying animal manure whose basic function on the farm is at least to maintain the resources of soil organic content.

\footnotetext{
${ }^{36}$ This paper also included an option for a farm to receive single area payment to afforested areas [Przewodnik..., 2016].
} 
Table 1. Farm income per 1 ha of UAA (PLN thousand) on farms identified by type of farming and natural farming conditions (according to the APAV index) based on the data of the Polish FADN 2013-2015

\begin{tabular}{|c|c|c|c|c|c|c|}
\hline \multirow{2}{*}{ Communes: } & \multicolumn{5}{|c|}{ Farms with: } \\
\cline { 2 - 7 } & field crops & $\begin{array}{c}\text { horticultural } \\
\text { crops }\end{array}$ & $\begin{array}{c}\text { permanent } \\
\text { crops }\end{array}$ & $\begin{array}{c}\text { grazing animals } \\
\text { in total }\end{array}$ & $\begin{array}{c}\text { granivores } \\
\text { in total }\end{array}$ & $\begin{array}{c}\text { mixed } \\
\text { production }\end{array}$ \\
\hline $\begin{array}{c}\text { with the average } \\
\text { APAV index } \\
\text { below 66.8 } \\
\text { points }\end{array}$ & 1.6 & 11.0 & 3.8 & 2.9 & 3.7 & 1.5 \\
\hline $\begin{array}{c}\text { with the average } \\
\text { APAV index of } \\
\text { at least 66.8 } \\
\text { points }\end{array}$ & 2.0 & 20.6 & 4.6 & 3.2 & 4.3 & 2.1 \\
\hline
\end{tabular}

Source: own study based on the data from the IUNG and Polish FADN in 2013-2015.

\subsection{Land afforestation financed from the RDP 2014-2020 in regional terms}

In 2004-2015 in Poland the area of potential UAA decreased by $2.7 \%$, i.e. by 524.4 thousand ha, and of wasteland - by $5.3 \%$, i.e. by 26.3 thousand ha [GUS 2007, 2016b]. The important reasons for this situation should be sought both in the increase in the area allocated for transport and housing purposes, as well as in the increased forestry land area. What is important, over the analysed period, the share of existing afforestations financed under the RDP 2014-2020 37 in the decrease in the area of potential agricultural land and wasteland in Poland amounted to $12.9 \%$. This means that afforestations financed under the RDP 2014-2020 have a noticeable impact on the change in the land use type.

The RDP 2014-2020 has financed so far 71.2 thousand ha of afforested land $^{38}$, of which coniferous, deciduous and mixed forests amounted to, respectively; 17.7, 8.8 and 44.7 thousand ha of land. The largest area of land was afforested in 2006 and 2007, respectively, 16.0 and 13.9 thousand ha (Figure 1). However, in recent years, the process of reducing the area of afforestation is in progress. In 2015 and 2016, 0.3 and 0.8 ha of land were afforested, respectively.

So far, $72.9 \%$ of total afforestations supported under the RDP 2014-2020 were made in the voivodeships with the average APAV index below the national average. The largest area of land was afforested in the Warmińsko-Mazurskie (17.1 thousand ha), Mazowieckie (7.3) and Zachodniopomorskie (6.3) Voivodeships while the smallest in the Śląskie (0.9), Opolskie (0.5) and Małopolskie (0.5) Voivodeships (Map 4).

\footnotetext{
${ }^{37}$ Status as of 31.12 .2016$.

${ }^{38}$ Status as of 31.12.2016.
} 
Figure 1. Area of afforestations made in 2004-2016 and financed under the RDP 2014-2020 (status as of 31.12.2016)

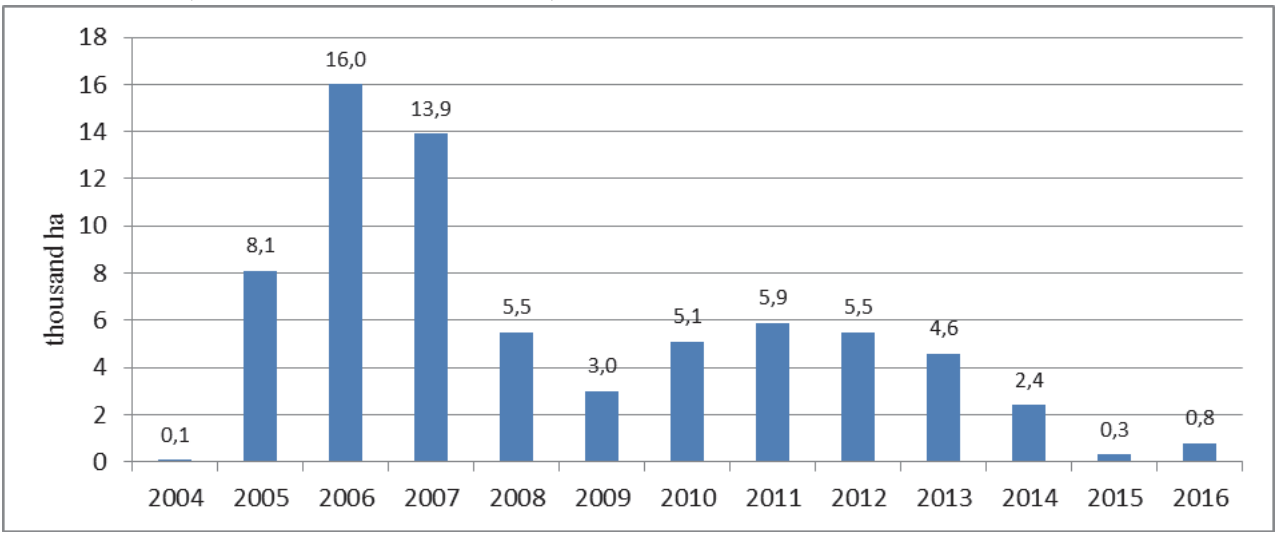

Source: own study based on the ARMA data.

Map 4. Area of coniferous, deciduous and mixed afforestations (ha) financed under the RDP 2014-2020 by voivodeship in Poland (status as of 31.12.2016)

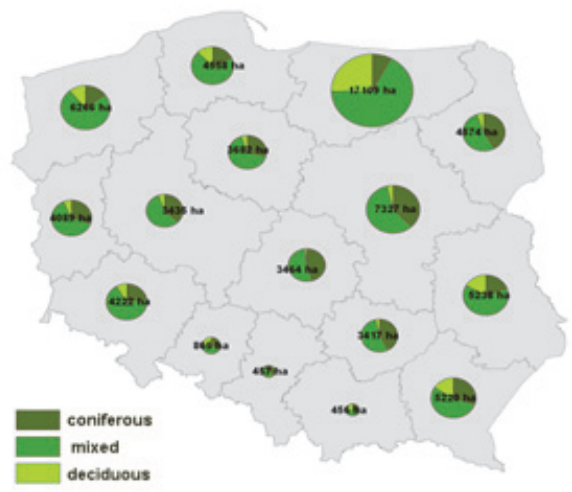

Source: own study based on the ARMiR and IUNG data.

In the case of the communes, the leading role was also played by afforestations in the communes with the average APAV index below the national average. In these types of communes, $70.9 \%$ of total afforestations supported under the RDP 2014-2020 were made, including 19.3\% in the communes with the APAV index below 52 points (Figure 2). In turn, the remaining $29.1 \%$ of afforestations were made in the communes with the APAV index of at least 66.8 points, and were dominated by afforestations $(83.2 \%)$ in the communes with the APAV index lower than 76.8 points. Definitely the lower share, accounting for, respectively, 10.0 and $6.8 \%$, was that of afforestations made in the communes with the APAV index of at least 76.8 points. 
Figure 2. Distribution (\%) of afforestations financed under the RDP 2014-2020 by APAV index in the communes in Poland (state as of 31.12.2016)
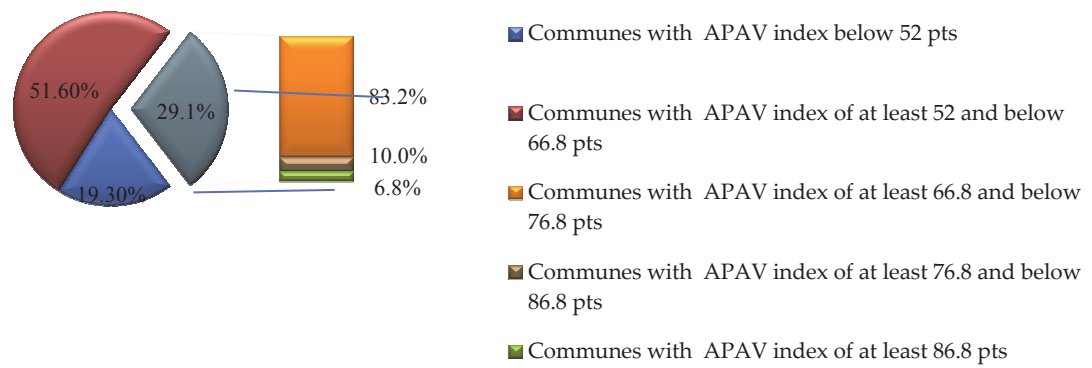

Source: own study based on the ARMiR and IUNG data.

\subsection{Importance of land afforestations financed under the RDP 2014-2020 in the EU climate policy for 2021-2030.}

According to the Proposal for the Regulation of the European Parliament and of the Council of 16 October 2017, Poland should reduce greenhouse gas emissions within the ESR area in 2021-2030 by 7\% when compared to the level of 2005 [Proposal for a Regulation, 2017]. Bearing in mind that according to the above, in the EU countries greenhouse gas emission reductions within the ESR area should cover all sectors, in this situation Poland will have to make efforts to reduce greenhouse gas emissions also in the agricultural sector, whose annual greenhouse gas emissions are at about $17 \%$ (in $2015-16.8 \%$ ) of the total greenhouse gas emissions within the $\mathrm{ESR}^{39}$ area (Figure 3).

It should be remembered that in the agricultural sector many contemporary greenhouse gas emission reduction practices can raise the production costs while not having any positive impact on its value ${ }^{40}$. In the light of the above, it is, therefore, appropriate to recognise two additional findings of the European Parliament and of the Council of 16 October 2017, which make it possible, in the selected EU countries (including Poland) to achieve more easily the objective of reducing greenhouse gas emissions within the ESR area in 2021-2030.

\footnotetext{
${ }^{39}$ The need to include the agriculture sector in reducing greenhouse emissions has also been included in the Communication from the Commission to the European Parliament, the Council, the European Economic and Social Committee and the Committee of the Regions of 29 November 2017 on The Future of Food and Farming. European Commission, 29.11.2017.

${ }^{40}$ The potential of reducing greenhouse gas emissions in Polish agriculture taking into account the effects of the Common Agricultural Policy. National Research Institute of Animal Production, University of Life Sciences in Lublin, Institute of Technology and Life Sciences, WULS, IERiGŻ-PIB, expert opinion for the MRiRW, Warsaw 2015.
} 
Figure 3. Structure (\%) of greenhouse gas emissions within the ESR area in Poland in 2015

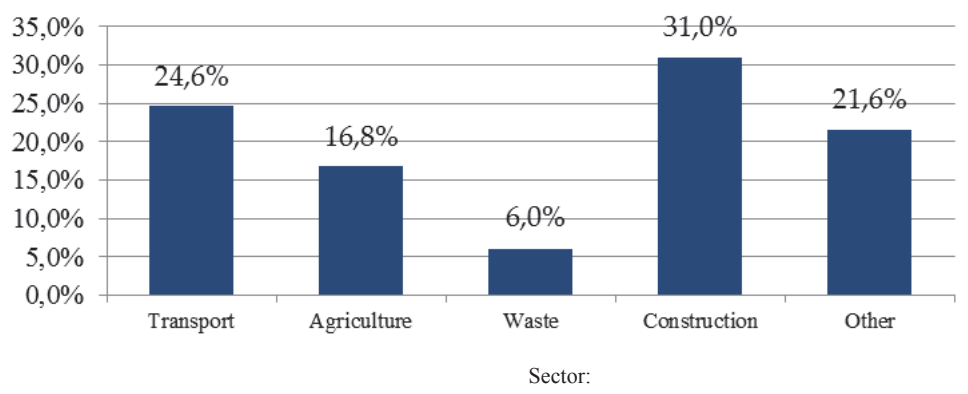

Source: own study based on KOBIZE [2017].

The first one applies to a possibility of using additional $\mathrm{CO}_{2}$ equivalent units as part of the security reserve $e^{41}$. The other allows to include a certain contribution of the LULUCF area therein. In this case, the possibilities of $\mathrm{CO}_{2}$ sequestration from the atmosphere in the LULUCF area likely to be used, to a certain extent, in limiting the effort to reduce greenhouse gas emissions from the ESR area in 2021-2030 should be sought, inter alia, in the afforestation sector. This is an advantage of this approach, as in this sector there are the possibilities of $\mathrm{CO}_{2}$ sequestration from the atmosphere. Taking into account the data from the National Centre for Emissions Management (KOBiZE) in Poland in 2015, the LULUCF area absorbed 29.9 million tonnes of $\mathrm{CO}_{2}$, including the afforested land sector -2.7 million tonnes of $\mathrm{CO}_{2}{ }^{42}$. Moreover, given that in 1995-2015 afforestations financed from the RDP 2014-2020 accounted for $25.7 \%$ in total afforestations, it can, therefore, be estimated that in 2015 those afforestations absorbed about 0.7 million tonnes of $\mathrm{CO}_{2}^{43}$ (Figure 4). In this context, it is necessary to highlight the positive importance of afforestations financed from the RDP 2014-2020 in the EU climate policy for 2021-2030.

\footnotetext{
${ }^{41}$ The security reserve in the selected EU countries will aim at easier achievement of the target of reducing greenhouse gas emissions within the ESR area in 2021-2030. It will be 115 million tonnes of $\mathrm{CO}_{2}$ eq. and it will be dedicated to the EU countries where, inter alia, GDP per capita is lower than the EU average and if their total emissions within the ESR area in 2013-2020 are below the established limits in 2013-2020 [Proposal for a Regulation, 2017].

${ }^{42}$ In Poland, the category of afforested land is the second largest source of $\mathrm{CO}_{2}$ sequestration in the LULUCF sector (the first largest largest source of $\mathrm{CO}_{2}$ sequestration in the LULUCF sector is the category of forestry land) [KOBIZE, 2017].

${ }_{43}$ According to the methodology of the Intergovermental Panel on Climate Change (IPCC), used by KOBiZE for the annual inventory of greenhouse gases in Poland, forestry land is treated as afforested land for 20 years from the moment of their afforestation. According to the GUS data, in Poland in 1995-2015, 276.7 ha of land were afforested [GUS, 2016a].
} 
Figure 4. Share of afforested land, including afforestations financed under the RDP in 2014-2020 in total CO2 sequestration in the LULUCF area in Poland in 2015

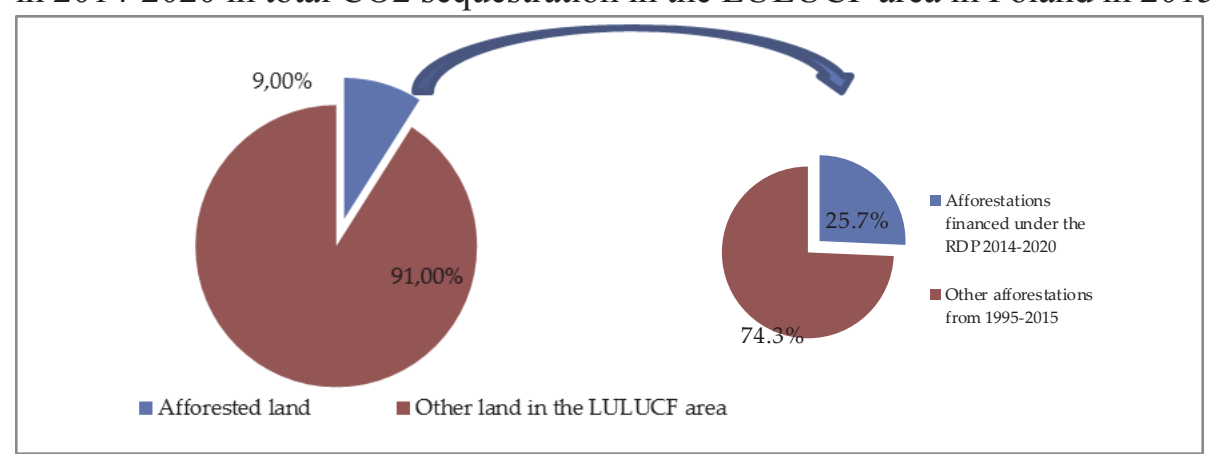

Source: own study based on the data from the ARMiR, GUS and KOBIZE [2017].

\subsection{Summary and conclusions}

In the first place, the study took account of natural farming conditions in Poland in regional terms, and their impact on the economic situation and the possibility of afforestation on farms. Then, it estimated the state of implementing afforestations financed under the RDP 2014-2020 in regional terms and their contribution to $\mathrm{CO}_{2}$ sequestration from the atmosphere in the LULUCF area. Analysis showed that:

- In Poland, there is the large share of potential UAA with low suitability for agriculture. It should be noted that $32.8 \%$ of cadastral districts have the average APAV index lower than 52 points per 120 achievable points. Therefore, these are the areas with land having the particularly unfavourable physical structure of soils and frequently negligible organic matter content. The worst situation in terms of the share of such poor soils in the potential area of UAA in total is in Podlaskie, Pomorskie and Małopolskie Voivodeships. Given the above, it should be stated that one of the alternatives to manage this type of land is afforestation. The more that on farms characterised by the absence or scarcity of animal manure and operating in the areas with unfavourable natural farming conditions, afforestation of their weakest land is economically reasonable.

- Afforestations financed under the RDP 2014-2020 have a noticeable impact on the change in the land use type. In 2004-2015, their share in the decrease in the area of potential UAA and wasteland in Poland amounted to $12.9 \%$. Moreover, so far, 72.9 and $70.9 \%$, respectively, of all afforestations supported under the RDP 2014-2020 were made in the voivodeships and communes with the average APAV index below the national average 
(66.8 pts). This means that existing afforestations are made mostly in the areas with the large share of poor soils with low suitability for agriculture.

- In recent years, there was a decrease in afforestations financed from the RDP 2014-2020. It should not be ruled out that the important reasons for this situation is the progressive process of increased specialisation and concentration of the agricultural production in Polish agriculture, which results in the increased production potential and economic power of farms and the possibility for potential beneficiaries to participate in other measures as part of the RDP 2014-2020, which strengthen their tendency to conduct the agricultural production. However, taking into account that in Poland there are still afforestation needs resulting from the large share of poor soils with low suitability for agriculture, it should be noted that farmers would still be willing to implement afforestations. Importantly, this tendency will probably be strengthened by the effects of climate change in a form of, inter alia, drought, currently escalating in Polish agriculture and resulting in the largest production losses on poorer soils.

- Taking into account the current findings of the European Parliament and of the Council on the EU climate policy for 2021-2030, it should be noted that afforestations financed under the RDP 2014-2020 will be able to contribute to limiting the effort to reduce greenhouse gas emissions from the ESR area, including agriculture after 2020. It is an important finding, as in the case of the agricultural sector the possibilities of further reducing greenhouse gas emissions without any loss to its economic effects are negligible.

\section{References}

1. Accounting data of farms from the Polish FADN database.

2. Communication from the Commission to the European Parliament, the Council, the European Economic and Social Committee and the Committee of the Regions of 29 November 2017 on The Future of Food and Farming. European Commission, Brussels.

3. Data from the database of the Agency for Restructuring and Modernisation of Agriculture.

4. Data from the database of the Institute of Soil Science and Plant Cultivation State Research Institute (IUNG) in Puławy.

5. GUS (2007). Rocznik statystyczny rolnictwa i obszarów wiejskich. Warsaw.

6. GUS (2010). Leśnictwo 2010. Warsaw.

7. GUS (2016a). Leśnictwo 2016. Warsaw.

8. GUS (2016b). Rocznik Statystyczny Rolnictwa. Warsaw. 
9. Jadczyszyn J., Kopiński J., Kuś J., Łopatka A., Madej A., Matyka M., Musiał W., Siebielec G. (2013). Rolnictwo na obszarach specyficznych. Agricultural Census 2010, GUS, Warsaw 2013

10. KOBiZE (2017). Poland's National Inventory Report 2017.

11.Krasowicz S., Oleszek W., Horabik J., Dębicki R., Jankowiak J., Stuczyński T., Jadczyszyn J. (2011). Racjonalne gospodarowanie środowiskiem glebowym Polski. Polish Journal of Agronomy, No 7.

12.Potencjał redukcji emisji gazów cieplarnianych w polskim rolnictwie z uwzględnieniem efektów Wspólnej Polityki Rolnej (2015). IZ - PIB, Uniwersytet Przyrodniczy w Lublinie, ITP, SGGW, IERiGŻ - PIB, ekspertyza wykonana dla MRiRW, Warszawa.

13.Proposal for a Regulation of the European Parliament and of the Council on the inclusion of greenhouse gas emissions and removals from land use, land use change and forestry into the 2030 climate and energy framework and amending Regulation No 525/2013 of the European Parliament and the Council on a mechanism for monitoring and reporting greenhouse gas emissions and other information relevant to climate change - general approach. Council of the European Union, Brussels.

14. Przewodnik po działaniu Zalesianie i tworzenie terenów zalesionych (2016). MRiRW, Warszawa.

15. Sytuacja emisyjna w sektorach non-ETS w perspektywie roku $2030 \mathrm{w}$ odniesieniu do potencjalnego celu redukcyjnego dla Polski (2016). MŚ, Warszawa 2016. 